\title{
PENGARUH CITRA MEREK DAN PROMOSI TERHADAP KEPUTUSAN PEMBELIAN
}

\author{
Cornelia Dumarya Manik ${ }^{1}$, Anthony Salim² ${ }^{2}$ Sugiyarto $^{3}$ \\ Dosen Universitas Pamulang \\ cornelia00720@unpam.ac.id ${ }^{1}$, anthony.salim4@gmail.com ${ }^{2}$, \\ sugiyarto_01722@unpam.ac.id ${ }^{3}$
}

\begin{abstract}
ABSTRAK
Penelitian ini bertujuan untuk mengetahui citra merek dan promosi obat paten Antibiotik Kimoxil pada outlet-outlet Apotek Kimia Farma di wilayah Jakarta Selatan khususnya Unit Bisnis Manajer Jaya 1 yang menaungi 32 (Tiga Puluh Dua) Apotek. Serta untuk mengetahui pengaruh antara citra merek dan promosi terhadap keputusan pembelian obat paten Antibiotik Kimoxil pada outlet-outlet Apotek Kimia Farma di wilayah Jakarta Selatan. Jenis penelitian ini adalah penelitian kuantitatif. Populasi dalam penelitian ini adalah seluruh dokter yang berpraktek di apotek Kimia Farma yang berada di wilayah jakarta selatan. Sampel yang digunakan dalam penelitian ini sebanyak 90 responden. Teknik pengumpulan data pada penelitian ini dengan cara kuesioner, dan teknik analisis data dengan uji validitas (uji normalitas, uji heteroskedastisitas, uji multikloinearitas, uji auto korelasi), uji reabilitas, uji asumsi klasik, uji regresi linear sederhana, uji regresi linear berganda, uji koefisien determinasi, uji koefisien korelasi, uji hipotesis parsial dan uji simultan. Hasil penelitian menunjukkan bahwa Citra Merek terbukti berpengaruh positif signifikan terhadap Keputusan Pembelian produk Kimoxil. Hal ini dapat ditunjukkan oleh nilai koefisien regresi sebesar 0,330, nilai thitung sebesar 3,868 lebih besar dari 1,662 dan nilai signifikansi sebesar 0,000 lebih kecil dari 0,05. Promosi terbukti berpengaruh positif dan signifikan terhadap Keputusan Pembelian, dalam hal ini dapat ditunjukkan oleh nilai koefisien regresi sebesar 0,569 , nilai thitung sebesar $3,858(3,858>1,662)$ dan nilai signifikansi sebesar 0,000 lebih kecil dari $0,05(0,000<0,05)$. Nilai koefisien korelasi juga menunjukkan bahwa nilai korelasi antara variabel Citra Merek dengan Keputusan Pembelian sebesar 0,634 masuk pada kategori "kuat". Sedangkan nilai korelasi antara Promosi dengan Keputusan Pembelian sebesar 0,634 dan masuk pada kategori kuat. Dengan kata lain, terdapat hubungan yang kuat antara variabel Citra Merek dan Promosi terhadap Keputusan Pembelian.
\end{abstract}

\section{Kata kunci : Citra Merek, Promosi, Keputusan Pembelian}

\section{ABSTRACT}

This study aims to determine the brand image and promotion of the patent drug Kimoxil Antibiotics at Kimia Farma Pharmacy outlets in the South Jakarta area, especially the Jaya 1 Manager Business Unit which houses 32 (Thirty Two) Pharmacies. As well as to determine the effect of brand image and promotion on purchasing decisions for Kimoxil Antibiotics patent drugs at Kimia Farma Pharmacy outlets in South Jakarta. This type of research is quantitative research. The population in this study were all doctors practicing at Kimia Farma pharmacy located in South Jakarta. The sample used in this study were 90 respondents. The data collection technique in this research is by means of a questionnaire, and data analysis techniques with validity test (normality test, heteroscedasticity test, multicloinearity test, auto correlation test), reliability test, classic assumption test, simple linear regression test, multiple 
linear regression test, test determination coefficient, correlation coefficient test, partial hypothesis test and simultaneous test. The results showed that the brand image proved to have a significant positive effect on purchasing decisions for Kimoxil products. This can be indicated by the regression coefficient value of 0.330 , the tcount value of 3.868 is greater than 1.662 and the significance value of 0.000 is less than 0.05. Promotion is proven to have a positive and significant effect on purchasing decisions, in this case it can be shown by the regression coefficient value of 0.569, the t-count value of 3.858 (3.858>1.662) and the significance value of 0.000, which is smaller than $0.05(0.000<0.05)$. The correlation coefficient value also shows that the correlation value between the Brand Image variable and the Purchase Decision is 0.634 in the "strong" category. Meanwhile, the correlation value between Promotion and Purchase Decision is 0.634 and is in the strong category. In other words, there is a strong relationship between Brand Image and Promotion variables on Purchasing Decisions.

Keywords: brand image, promotion, purchasing decisions

\section{PENDAHULUAN}

Pada dasarnya dengan semakin banyaknya pesaing maka semakin banyak pula pilihan bagi pelanggan untuk dapat memilih produk yang sesuai dengan apa yang menjadi harapannya. Sehingga konsekuensi dari perubahan tersebut adalah pelanggan menjadi lebih cermat dan pintar dalam menghadapi setiap produk yang beredar di pasar. Salah satu cara yaitu perusahaan melebarkan sayapnya memperluas pasar untuk mendapatkan tempat di hati konsumen. Karena konsumen merupakan sebagai tolak ukur keberhasilan perusahaan, bagi seorang pemasar harus dapat mengetahui apa yang di butuhkan oleh konsumen, pemasar harus bisa menyusun strategi untuk memuaskan kebutuhan konsumen, dimana kebutuhan konsumen akan bergerak dinamis sesuai dengan perkembangan zaman, sehingga para pemasar harus membaca setiap perubahan selera dan minat konsumennya. Persaingan yang begitu ketat dewasa ini menuntut perusahaanperusahaan agar mampu memainkan strategi pemasaran yang handal dan mampu menarik minat konsumen sehingga dapat memenangkan pasar. Perusahaan sudah semestinya lebih terfokus pada konsumen agar dapat memenangkan persaingan. Dengan memberikan kepuasan pada konsumen maka akan dapat membangun kepercayaan konsumen dan akhirnya tercipta hubungan yang erat antara konsumen dan perusahaan. menurut konsep pemasaran, perusahaan yang bisa bertahan dan memenangkan persaingan di pasar global adalah perusahaan yang mampu menawarkan nilai lebih dan sesuai dengan keinginan pelanggan.

Oleh karena itu untuk mencapai kesuksesan perusahaan harus memenuhi 
syarat yang harus dipenuhi agar dapat mencapai sukses dalam persaingan. Misalnya seperti mencapai tujuan untuk menciptakan dan mempertahankan pelanggan. Agar tujuan tersebut tercapai, maka setiap perusahaan harus berupaya menghasilkan dan menyampaikan barang dan jasa yang di inginkan konsumen dengan harga yang sesuai. Dengan demikian, setiap perusahaan harus mampu memahami perilaku konsumen pada pasar sasarannya, karena kelangsungan hidup perusahaan tersebut sebagai organisasi yang berusaha memenuhi kebutuhan dan keinginan para konsumen sangat tergantung pada perilaku konsumennya. Perilaku konsumen harus diketahui perusahaan sebagai strategi dalam menarik pasar.

Indonesia merupakan salah satu negara yang padat akan penduduknya, produsen saling berlomba untuk masuk ke dalamnya, karena Indonesia merupakan salah satu penduduk terbesar didunia, pada tahun 2019 penduduk Indonesia mencapai 260 juta jiwa dan diperkirakan setiap tahunya akan bertambah sekitar 1,62\% . Oleh karena itu Indonesia negara potensial untuk berbisnis, khususnya pada bidang obat-obatan bermerek, karena obat Antibiotik merupakan kebutuhan setiap orang yang memiliki penyakit baik penyakit kronis maupun menahun (Akut). Masyarakat sudah lebih sadar dan peduli akan kesehatan dan kebersihan pada dirinya, karena itu bisa membuat orang tersebu bisa lebih percaya diri untuk berkomunikasi.

Selain itu masyarakat juga lebih diyakini oleh kegiatan kegiatan sosial yang dilakukan oleh perusahaan-perusahaan produk obat-obatan, yang melakukan penyuluhan maupun transfer ilmu akan pentingnya kesehatan kepada masyarakat, serta sosialisasi akan pentingnya penggunaan antibiotik secara terus-menerus yang berakibat resistensi kepada masyarakat.

\section{Tabel 1.1}

Data Penjualan Kimoxil wilayah Jakarta Selatan Periode 2015 - 2019

Tahun Target Realisasi Persentase

$\begin{array}{llll}2015 & 1.016 & 537 & 52,8 \% \\ 2016 & 1.236 & 912 & 73,78 \% \\ 2017 & 1.653 & 1.128 & 68,23 \% \\ 2018 & 1.947 & 1.524 & 78,27 \% \\ 2019 & 2.280 & 1.934 & 84,82 \% \\ \text { Total } & 8.132 & 6.060 & 74,5 \%\end{array}$

Sumber: PT. Pharmasolindo area Jakarta Selatan tahun 2020

Dari Hasil riset yang didapatkan menyatakan bahwa penjualan Kimoxil pada tahun 2015 menunjukkan realisasi yang cukup baik meskipun grafik persentase yang ada di tabel tersebut hanya mencapai $52,8 \%$ karena ketidaksiapan pabrik dalam 
menyiapkan stok bahan baku untuk kebutuhan setahun dan pada akhirnya terjadi kekosongan pada periode bulan Agustus hingga September 2015.

Pada tahun 2016 penjualan menunjukkan kenaikan persentase yang cukup signifikan, namun tidak pernah mencapai realisasi dari target yang diinginkan, karena keterlambatan produksi dari pabrik. Sedangkan pada tahun 2017 Penjualan produk Kimoxil kembali mengalami penurunan akibat renovasi pabrik betalaktam yang berada dibandung sehingga plant produksi pun akhirnya dialihkan ke PT. Rama Emerald yang berada di Kota Gresik, Provinsi Jawa Timur sehingga penjualan dari target yang sudah direncanakan kembali tidak tercapai. Pada tahun 2018 penjualan produk Kimoxil kembali menunjukkan kenaikan persentase sebesar $10 \%$ dari tahun sebelumnya, sebagai akibat dari melimpahnya stok produksi produk di Pabrik, namun jika dilihat dari pencapaian target penjualan tersebut kembali tidak tercapai $100 \%$ dari target yang direncanakan.

Pada Tahun 2019 permasalahan kembali timbul akibat tidak tercapainya target dan pengiriman bahan baku yang cukup lama serta izin dari BPOM yang cukup lama keluar, sehingga stok dari pabrik pun terbatas dan mengalami kekosongan produk sejak bulan Agustus 2019 hingga Desember 2019.

Dari hasil riset tersebut dapat disimpulkan bahwa terjadi permasalahan yang cukup signifikan dan berpengaruh terhadap keputusan pembelian sebagai akibat dari tidak tercapainya target penjualan dalam periode selama 5 tahun tersebut. Kotler dan Keller (2016:345), mendefinisikan "brand image sebagai sekumpulan persepsi dan kepercayaan yang dimiliki oleh pelanggan terhadap suatu brand yang direfleksikan melalui asosiasiasosiasi yang ada dalam ingatan pelanggan".

Dari pernyataan tersebut membuktikan bahwa citra merek dapat memberikan keyakinan bagi konsumen dalam melakukan pembelian suatu produk. Karena persepsi kualitas merupakan persepsi konsumen maka dapat diramalkan jika persepsi kualitas konsumen negatif, produk tidak akan disukai dan tidak akan bertahan lama di pasar. Sebaliknya, jika persepsi kualitas pelanggan positif, produk akan disukai, dengan beranggapan bahwa kualitas produk yang baik merupakan jaminan kepuasan dalam menggunakan produk tersebut untuk memenuhi kebutuhan hidupnya. Dengan persepsi kualitas yang baik akan menciptakan suatu image yang baik bagi suatu produk yang akan menimbulkan keputusan pembelian 
oleh konsumen. Citra merek adalah seperangkat keyakinan, ide, dan kesan yang dimiliki oleh seseorang terhadap suatu merek.

\section{Tabel 1.2}

\section{Top Brand Index obat paten Antibiotik} Periode 2015-2019

\begin{tabular}{lccccc} 
Merek & \multicolumn{5}{c}{ Tahun } \\
& 2015 & 2016 & 2017 & 2018 & 2019 \\
Kimoxil & $35.7 \%$ & $47,8 \%$ & $52,8 \%$ & $54,5 \%$ & $62,3 \%$ \\
Amoxsan & $85,1 \%$ & $83,4 \%$ & $86,7 \%$ & $89,6 \%$ & $93,7 \%$ \\
Dexymox & $39,7 \%$ & $32,6 \%$ & $35,9 \%$ & $29,4 \%$ & $27,6 \%$ \\
Kalmoxillin & $41,2 \%$ & $45,5 \%$ & $43,2 \%$ & $56,8 \%$ & $52,9 \%$ \\
Lain-lain & $31,7 \%$ & $23,8 \%$ & $19,4 \%$ & $18,8 \%$ & $15,6 \%$ \\
\multicolumn{5}{c}{ Sumber : PT. Pharmasolindo tahun 2019 }
\end{tabular}

Dilihat dari data market share yang ada Amoxsan (Sanbe Farma) masih menjadi market leader selama 5 (lima) tahun berturut-turut meskipun mengalami penurunan pasar pada tahun 2016 Amoxsan kembali bangkit pada tahun 2017 dan pada akhirnya kembali mengalami penurunan penjualan pada tahun 2018, sedangkan pada tahun 2019 kembali mengalami peningkatan yang tidak terlalu signifikan, penurunan ini sebagai akibat dari pembatasan pengunaan Antibiotik oleh Kementrian Kesehatan.

Sedangkan Kimoxil (Kimia Farma) mengalami pertumbuhan cukup signifikan setiap tahunnya ditengah keterbatasan dan kendala produksi yang ada akibat dari renovasi pabrik serta pemindahan plant produksi ke PT. Rama Emerald. Dimulai dari tahun 2015 Kimoxil mulai menjadi pilihan utama dari dokter inhouse yang ada di Kimia Farma Apotek unit bisnis Jaya 1, meskipun pada saat itu cabang apotek tersebut hanya 20 cabang tetapi penjualan Kimoxil terus merangkak pada tahun berikutnya, Tahun 2016 mengalami penjualan yang cukup signifikan sehingga mulai dapat bersaing dengan Amoxsan yang menjadi market leader dan penjualan yang naik terus terjadi pada tahun 2017 , pada tahun ini Kimoxil sudah mulai mencapai penjualan per unitnya mencapai 1000 (seribu) dus per tahun dengan rata-rata penjualan per bulan sebanyak 94 dus, dan pada tahun 2018 selisih penjualan dengan market leader Amoxsan sudah mulai menipis dengan selisih kurang lebih $15 \%$, sang market leader pun makin tergerus akibat dari pembayaran tagihan apotek yang lewat dari jatuh tempo dan pada akhirnya tahun 2019 pun menjadi persaingan yang cukup ketat antara Amoxsan dan Kimoxil pun terjadi meskipun belum dapat mengalahkan sang market leader Kimoxil mampu menunjukkan promosi secara masif dengan banyaknya program-program yang ditawarkan kepada stakeholder seperti Apotek dan mitra-mitra lainnya.

Produk-produk sejenis lainnya seperti Dexymox (Dexa Medica) dan Kalmoxicillin (Kalbe Farma) hanya mengikuti perkembangan pasar yang ada meskipun hanya meraih penjualan yang 
tidak banyak seperti 2 (Dua) lawannya diatas, kedua produk tersebut hanya dijadikan alternatif oleh dokter sebagai pilihan cadangan apabila Amoxsan dan Kimoxil mengalami kekosongan stok di apotek cabang, sementara itu diantara kedua produk yang berada dibawah tersebut Kalmoxillin cukup mengambil pangsa pasar cukup besar di awal tahun penelitian ini dan pada tahun 2016 produk tersebut mengalami peningkatan yang cukup signifikan, produk dari pabrikan Kalbe Farma ini cukup mempromosikan produk tersebut secara masif meskipun terus mengalami penurunan setiap tahunnya, dimulai sejak tahun 2017 Kalmoxillin mengalami penurunan penjualan yang cukup signifikan.

Sementara itu Dexymox hanya mengikuti diposisi paling bawah dengan penjualan yang cukup stabil namun menurun setiap tahunnya, produk ini pun hanya mengambil sisa market yang ada dan menjadi juru kunci diantara ketiga produk yang disebutkan diatas.

Sisa pasar yang lain pun mengikuti perkembangan pasar dengan promosi yang terbatas dan demand pasar yang cukup kecil obat-obatan seperti Intermoxil (Interbat), Amoxil (GSK) dan Topcillin (Dankos).

Dari semua data Top Brand Index diatas dapat disimpulkan bahwa Citra Merek dan Promosi sangatlah berpengaruh terhadap proses, pencapaian penjualan dan keputusan pembelian oleh konsumen. Promosi yang masif dengan pemberian insentif kepada karyawan maupun stakeholder yang ada sehingga menciptakan demand pasar yang cukup besar sehingga dapat menguasai pasar dengan penjualan yang besar dan market share yang besar. Promosi pada intinya merupakan ujung tombak sebuah perusahaan dengan tenaga pemasar yang profesional dan terampil, dengan mengandalkan skill dan kompetensi yang terlatih dan cakap dalam memasarkan sebuah produk. Kegiatan promosi bukan saja berfungsi sebagai alat komunikasi antara perusahaan dengan konsumen, melainkan juga sebagai alat untuk memengaruhi konsumen dalam kegiatan pembelian atau penggunaan produk sesuai dengan kebutuhan dan keinginannya.

Promosi juga merupakan faktor penting dalam mewujudkan tujuan penjualan suatu perusahaan. Agar konsumen bersedia menjadi langganan, mereka terlebih dahulu harus dapat mencoba atau meneliti barang-barang yang diproduksi oleh perusahaan, akan tetapi mereka tidak akan melakukan hal tersebut jika kurang yakin terhadap barang itu. Disinilah perlunya mengadakan promosi yang terarah, karena diharapkan dapat memberikan pengaruh positif terhadap meningkatnya penjualan". 
Kegiatan promosi obat paten diantaranya melalui Personal Selling yang dapat dilakukan melalui RTD (Round on Table Presentation), Gathering dokter dan para frontliner, product knowledge untuk apotek, pemberian voucher belanja serta pemberian bonus penjualan per dus dan pemberian Reward tour trip ke luar negeri. Kegiatan Personal Selling ini biasanya dapat dilakukan setiap waktu pada saat yang bersamaan dan sesuai dengan ketentuan perusahaan masing-masing.

\section{Tabel 1.3}

\section{Program Promosi Obat Paten Antibiotik} Kimoxil

Periode Tahun 2017 - 2019

\begin{tabular}{|c|c|c|c|c|}
\hline \multirow{2}{*}{\multicolumn{2}{|c|}{ Kegiatan Promosi }} & \multicolumn{3}{|c|}{ Tahun } \\
\hline & & 2017 & 2018 & 2019 \\
\hline \multirow[t]{4}{*}{ Iklan } & 1. Brosur & Tidak & Ada & Ada \\
\hline & 2. List Produk & Tidak & Tidak & Ada \\
\hline & 3. Leaflet/Flyer & Ada & Ada & Ada \\
\hline & 4. Spanduk & Ada & Tidak & Tidak \\
\hline \multicolumn{5}{|c|}{ Promosi Penjualan } \\
\hline & 1. Majalah Mingguan & Ada & Tidak & Tidak \\
\hline & 2. Event Ilmiah & Ada & Ada & Ada \\
\hline & 3. Gathering Dokter & r Tidak & Tidak & Ada \\
\hline & 4. Produk Knowled & ge Ada & Ada & Tidak \\
\hline & 5. Round Table Disc & c. Tidak & Ada & Ada \\
\hline
\end{tabular}

Sumber : PT. Pharmasolindo tahun 2019

Berdasarkan Tabel 1.3 diatas promosi yang dilakukan oleh PT. Pharmasolindo menunjukkan bahwa pada periode program tersebut beberapa kegiatan promosi yang sudah dilakukan sudah cukup baik pada periode tahun 2017 beberapa kegiatan promosi tidak dapat dilakukan seperti pengadaan brosur list produk berupa literatur produk Gathering Dokter dan Round Table Discussion.

Sedangkan pada tahun 2018 seiring dengan kosongnya produk dari pabrik program yang sudah dilakukan sudah mulai menunjukkan perbaikan, namun beberapa program belum dapat dilaksanakan seperti Gathering dokter karena ada beberapa dinamika yang terjadi seperti perubahan tim Field Force dan perubahan produk/divisi.

Dan pada tahun 2019 program yang dijalankan sudah mulai menunjukkan peningkatan seperti Gathering dokter dan Round Table Discussion masyarakat yang kembali diadakan, ada beberapa program yang tidak dapat dilanjutkan juga seperti Product knowledge karena pergantian kepala cabang yang mempengaruhi keputusan pembelian dan penjualan.

Tabel 1.4

Jumlah Pasien pembeli produk Kimoxil Periode Tahun 2015-2019

\begin{tabular}{|c|c|}
\hline Tahun & Jumlah Pasien \\
\hline 2015 & 208 \\
\hline 2016 & 110 \\
\hline 2017 & 192 \\
\hline 2018 & 229 \\
\hline 2019 & 187 \\
\hline Total & $\mathbf{9 4 6}$ \\
\hline
\end{tabular}

Sumber : PT. Kimia Farma Apotek Tahun 2020

Berdasarkan tabel diatas dapat diketahui bahwa jumlah pasien yang merupakan pembeli produk Kimoxil setiap 
tahun mengalami siklus fluktuatif sejak tahun 2016 jumlah pasien tersebut mengalami penurunan yang cukup signifikan dari tahun 2015, pada tahun 2017 peningkatan penjualan dan puncak dari jumlah pasien pembeli produk tersebut terjadi pada tahun 2018, sedangkan pada tahun 2019 jumlah tersebut kembali mengalami penurunan ditengah adanya pelarangan penjualan obat antibiotik secara bebas oleh Badan Pengawas Obat dan Makanan (BPOM).

Berdasarkan dari latar belakang masalah yang telah diuraikan tersebut diatas, penulis tertarik untuk melakukan penelitian tentang "Pengaruh Citra Merek Dan Promosi Terhadap Keputusan Pembelian (studi kasus Pengguna Produk Antibiotik Kimoxil di Wilayah Jakarta Selatan)".

\section{TINJAUAN PUSTAKA}

\section{Keputusan Pembelian}

Kotler \& Keller mengemukakan bahwa "perilaku konsumen berkaitan erat dengan perilaku yang dilakukan dalam melakukan keputusan pembelian akhir, pembelian yang dilakukan oleh individu atau rumah tangga untuk dikonsumsi secara pribadi”.

\section{Pengertian Citra (Image)}

Image (Citra) adalah persepsi masyarakat terhadap perusahaan atau produknya. Image dipengaruhi oleh banyak faktor yang di luar kontrol perusahaan.

Demi mengembangkan citra yang kuat membutuhkan kreatifitas dan kerja keras. Citra tidak dapat ditanamkan dalam pikiran manusia dalam semalam atau disebarkan melalui media masa. Sebaliknya, citra itu harus disampaikan melalui tiap sarana komunikasi yang tersedia dan disebarkan secara terus menerus.

Untuk berhasil memperoleh dan mempertahankan konsumenmya maka perusahaan harus berusaha semaksimal mungkin untuk menampilkan produk dengan memiliki citra merek (brand image) yang positif di mata konsumen. Dengan menampilkan produk yang memiliki citra merek yang positif dapat mempertinggi kepercayaan konsumen terhadap produknya dan mendorong konsumen semakin lama akan menjadi konsumen yang loyal terhadap produknya tersebut. Menurut Alma (2017) “citra merek adalah merupakan impresi, perasaan atau konsepsi yang ada pada publik mengenai perusahaan, mengenai suatu objek, orang atau mengenai lembaga".

Promosi adalah arus informasi atau persuasi satu arah yang dibuat untuk mengarahkan seseorang atau organisasi 
kepada tindakan yang menciptakan pertukaran dalam pemasaran. Pengertian promosi menurut. Menurut Kotler dan Amstrong (2016:408), "promosi adalah suatu alat untuk berkomunikasi pembeli dan perusahaan lain yang bertujuan untuk merubah memberikan informasi secara lugas". Adapun alat-alat dan kebutuhan yang dapat dipergunakan untuk mempromosikan suatu produk dapat dipilih beberapa cara, yaitu iklan, promosi penjualan, publisitas, personal selling yang disebut bauran promosi.

\section{METODE PENELITIAN}

\section{Populasi dan Sampel}

1. Populasi

Menurut Sugiyono (2015:80), menyatakan bahwa "populasi adalah wilayah generalisasi yang terdiri atas: obyek atau subyek yang mempunyai kualitas dan karakteristik tertentu yang ditetapkan oleh peneliti untuk dipelajari kemudian ditarik kesimpulannya". Populasi dari penelitian ini mencakup pasien yang membeli produk Kimoxil dengan jumlah sebanyak 946 responden sejak tahun 2015 hingga 2019 di Kimia Farma Apotek Wilayah Jakarta Selatan.

2. Sampel

Menurut Sugiyono (2015:120), "Sampel adalah bagian dari jumlah karakteristik yang dimiliki oleh populasi tersebut'. Bila populasi besar, dan peneliti tidak mungkin mempelajari semua yang ada pada populasi, misalnya karena keterbatasan dana, tenaga dan waktu maka peneliti dapat menggunakan sampel yang diambil dari populasi itu. Pengambilan sampel didasarkan pertimbangan bahwa responden pernah meresepkan atau mengkonsumsi produk Kimoxil. Sampel yang akan dipilih oleh penulis sebagai sumber data yang dibutuhkan untuk penelitian ini adalah para pasien yang merupakan pembeli produk Kimoxil. Dalam penelitian ini menggunakan probability sampling. Menurut Sugiyono $\quad(2017: 118)$ "probability sampling adalah teknik pengambilan sampling yang memberikan peluang yang sama bagi setiap anggota populasi untuk dipilih menjadi anggota sampel”.

$$
\text { Menurut Sugiyono }
$$
berpendapat "dalam sebuah penelitian jika jumlah populasinya dianggap terlalu besar maka penulis dapat mempersempit populasi dengan cara menghitung ukuran sampel yang dilakukan dengan menggunakan teknik Slovin agar representatif dan hasilnya dapat digereralisasikan".

Dengan demikian penentuan jumlah sampel dalam penelitian ini dilakukan dengan 
perhitungan sederhana memakai rumus slovin sebagai berikut:

$$
\mathrm{n}=\frac{\mathrm{N}}{1+\mathrm{N}(\mathrm{e})^{2}}
$$

Keterangan :

$\mathrm{n}=$ Ukuran sampel

$\mathrm{N}=$ Ukuran populasi

$=$ Toleransi error $(10 \%)$

Dengan menggunakan rumus diatas, maka diperoleh perhitungan sebagai berikut:

Sampel penelitian adalah 946 pasien yang merupakan pembeli produk Kimoxil sejak tahun 2015 hingga sampai pada tahun 2019

$$
\begin{aligned}
\mathrm{n} & =\frac{946}{1+946(0,010)} \\
& =\frac{946}{1+9,46} \\
& =90,43 \text { atau dibulatkan } 90
\end{aligned}
$$

\section{Teknik Pengumpulan Data}

1. Observasi

Menurut Sugiyono (2015:141), “observasi merupakan suatu proses yang tersusun dari berbagai proses sehingga diperoleh data berdasarkan fakta mengenai dunia kenyataan yang diperoleh melalui observasi". Tujuan dari observasi adalah untuk melengkapi data yang diperlukan serta membandingkan keterangan yang diperoleh sebelumnya dengan fakta yang ada dilapangan.

\section{Angket (Kuesioner)}

Menurut Sugiyono (2015:142), "kuesioner merupakan teknik pengumpulan data yang efisien apabila peneliti tahu dengan siapa variabel akan diukur dan tahu apa yang bisa diharapkan dari responden". Kuesioner dilakukan dengan cara memberikan sejumlah pertanyaan dan pernyataan yang tertulis kepada responden untuk menjawab Pertanyaan-pertanyaan pada angket tertutup dibuat dengan skala Likert 1-5 dengan menggunakan 44 pertanyaan berskala. Menurut Sugiyono (2015:93), "skala Likert adalah skala yang digunakan untuk mengukur sikap, pendapat, dan persepsi seseorang atau sekelompok orang tentang fenomena sosial". Dengan skala Likert, maka variabel yang akan diukur, 8dijabarkan menjadi indikator variabel. Kemudian indikator tersebut dijadikan sebagai titik tolak untuk menyusun item-item instrument yang dapat berupa pernyataan atau pertanyaan.

3. Studi Kepustakaan

Studi pustaka, menurut Nazir (2013:93) teknik pengumpulan data dengan mengadakan studi penelaah terhadap bukubuku, literatur-literatur, catatan-catatan, dan laporan-laporan yang ada hubungannya dengan masalah yang dipecahkan. Teknik ini digunakan untuk memperoleh dasardasar dan pendapat secara tertulis yang dilakukan dengan cara mempelajari 
berbagai literatur yang berhubungan dengan masalah yang diteliti. Hal ini juga dilakukan untuk mendapatkan data sekunder yang akan digunakan sebagai landasan perbandingan antara teori dengan prakteknya di lapangan. Data sekunder melalui metode ini diperoleh dengan browsing di internet, membaca berbagai literatur, hasil kajian dari peneliti terdahulu, catatan perkuliahan, serta sumber-sumber lain yang relevan.

\section{Teknik Analisis Data}

Teknik analisis yang digunakan dalam penelitian ini adalah analisis regresi sederhana. Metode ini bertujuan untuk menggambarkan sifat sesuatu yang tengah berlangsung pada saat riset dilakukan dan memeriksa sebab-sebab dari suatu gejala tertentu (Trevers, 1978 dalam Umar, 2016:81).

1. Statistik Deskriptif

Statistik deskriptif adalah statistik yang digunakan untuk menganalisis data dengan cara menjelaskan gambaran data yang telah terkumpul sebagaimana adanya atau aslinya tanpa bermaksud untuk membuat kesimpulan yang berlaku secara umum (Sugiyono, 2012:147).

2. Uji Validitas

Validitas merupakan sejauh mana ketepatan dan kecermatan suatu alat ukur dalam melakukan fungsi ukurnya. Pengukuran dikatakan valid jika mengukur tujuannya dengan nyata atau benar (Sugiyono, 2012:455).

Suatu variabel penelitian dikatakan valid apabila memenuhi kriteria sebagai berikut:

a. Bila $\mathrm{r}$ hitung $>\mathrm{r}$ table, maka dinyatakan valid.

b. Bila $r$ hitung $<\mathrm{r}$ table, maka

Pembelian sebesar 0,643 masuk pada kategori "kuat". Sedangkan nilai korelasi antara Promosi dengan Keputusan Pembelian sebesar 0,634 dan masuk pada kategori kuat. Dengan kata lain, terdapat hubungan yang kuat antara variabel Citra Merek dan Promosi terhadap Keputusan Pembelian.

3. Uji Regresi Linear Sederhana

Tabel 4.17

Uji Regresi Linear Sederhana Pengaruh Citra Merek terhadap Keputusan Pembelian

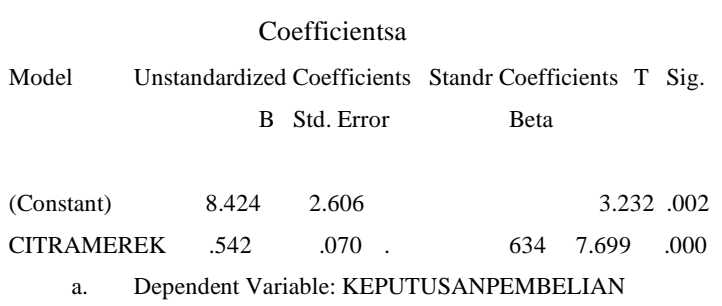

Sumber: Hasil Olah Data SPSS versi 25, 2020

Berdasarkan hasil olah data di atas, maka dapat dikemukakan persamaan regresi linear sederhana sebagai berikut: Y $=\mathrm{a}+\beta \mathrm{X}$ $\mathrm{Y}=8.424+0.542 \mathrm{X}$ 
Keterangan:

$\mathrm{Y} \quad=$ Keputusan Pembelian

$\mathrm{a}($ konstanta $)=8,424$

$\mathrm{b}($ koefisien regresi $)=$ Variabel Citra Merek sebesar 0,542

Berdasarkan penjelasan diatas bahwa nilai konstanta sebesar 8,424 memiliki arti, meskipun tidak ada pengaruh dari variabel Citra Merek, Keputusan Pembelian Obat paten Antibiotik Kimoxil sebesar 8,424 .

Tabel 4.18

Uji Regresi Linear Sederhana

Pengaruh Promosi terhadap Keputusan

Pembelian

Coefficientsa

Model Unstd.Coefficients Std Coefficients $t$ Sig. B Std. Error Beta

$\begin{array}{lllll}\text { (Constant) } & 9.217 & 2.506 & 3.677 & .000\end{array}$

$\begin{array}{lllllll}\text { PROMOSI } & .936 & .122 & .634 & 7.691 & .000\end{array}$

a. Dependent Variable: KEPUTUSANPEMBELIAN

Sumber: Hasil Olah Data SPSS versi 25, 2020

Berdasarkan hasil olah data di atas, maka dapat dikemukakan persamaan regresi linear sederhana sebagai berikut: $Y=a+\beta X$ $\mathrm{Y}=9.217+0.936 \mathrm{X}$

Keterangan:

$\mathrm{Y}=$ Keputusan Pembelian

$\mathrm{a}($ konstanta $)=9.217$

b $($ koefisien regresi $)=$ Variabel Promosi sebesar 0.936

Berdasarkan penjelasan diatas bahwa nilai konstanta sebesar 8,424 memiliki arti, meskipun tidak ada pengaruh dari variabel Citra Merek, Keputusan
Pembelian Obat paten Antibiotik Kimoxil sebesar 8,424 .

\section{KESIMPULAN DAN SARAN}

\section{Kesimpulan}

Setelah penulis melakukan penelitian dan menganalisis mengenai Pengaruh Citra Merek, Promosi terhadap Keputusan Pembelian Obat Antibiotik Kimoxil di Wilayah Jakarta Selatan, maka penulis dapat menarik kesimpulan sebagai berikut:

1. Berdasarkan Uji Regresi Linear Berganda yang didapat dari hasil Citra Merek terhadap Keputusan Pembelian, diketahui nilai t sebesar 3,868 dengan nilai sig. Sebesar 0,000 (artinya nilai sig tersebut < 0.05) maka dapat disimpulkan H0 ditolak dan $\mathrm{Ha}$ diterima, yang berarti ada pengaruh yang signifikan variabel Citra Merek (X1) terhadap Keputusan Pembelian (Y) dari pengujian Hipotesis diperoleh nilai t nilai thitung > ttabel $(7,699>$ 1,662) hal itu juga dibuktikan dengan signifikansi $0,000<0,05$. Dengan demikian maka H0 ditolak dan H1 diterima, hal ini menunjukkan bahwa terdapat pengaruh positif dan signifikan secara parsial antara "Pengaruh Citra Merek terhadap Keputusan Pembelian” produk Obat Antibiotik Kimoxil. 
2. Berdasarkan Uji Regresi Linear Berganda yang didapat dari hasil Promosi terhadap Keputusan Pembelian, diketahui nilai $\mathrm{t}$ sebesar 3,858 dengan nilai sig. Sebesar 0,000 (artinya nilai sig tersebut $<0.05$ ) maka dapat disimpulkan $\mathrm{H} 0$ ditolak dan $\mathrm{Ha}$ diterima, yang berarti ada pengaruh yang signifikan variabel Promosi (X2) terhadap Keputusan Pembelian (Y) dari pengujian Hipotesis diperoleh nilai $\mathrm{t}$ nilai thitung > ttabel $(7,691>1,662)$ hal itu juga dibuktikan dengan signifikansi $0,000<0,05$. Dengan demikian maka $\mathrm{H} 0$ ditolak dan $\mathrm{H} 2$ diterima, hal ini menunjukkan bahwa terdapat pengaruh positif dan signifikan secara parsial antara "Pengaruh Promosi terhadap Keputusan Pembelian" produk Obat Antibiotik Kimoxil.

3. Berdasarkan hasil penelitian Uji f, menunjukkan bahwa terdapat bahwa Citra Merek dan Promosi secara simultan berpengaruh positif dan signifikan terhadap keputusan pembelian. Dengan nilai $F$ hitung sebesar 59,154 lebih besar dari F tabel sebesar 2,71 dan nilai signifikansi sebesar 0,000 lebih kecil dari 0,05. Semakin besar pengaruh Citra Merek dan Promosi maka akan semakin meningkat Keputusan Pembelian. Demikian pula sebaliknya, jika Citra
Merek dan Promosi rendah maka akan juga semakin menurun.

\section{DAFTAR PUSTAKA}

Ayuwardani, Rizky Primadita. Pengaruh Informasi Keuangan Dan Non Keuangan Terhadapa Underpricing Harga Saham Pada Perusahaan Yang Melakukan Initial Public Offering (Studi Empiris Perusahaan Go Public yang terdaftar di Bursa Efek Indonesia Tahun 2011-2015). Jurnal Nominal Vol. 7, No.1, 2018.

Ayuniah, Putri (2015). Analisis Pengaruh Citra Merek, Kualitas Produk, Iklan, Dan Harga Terhadap Keputusan Pembelian Produk Kosmetik Wardah. Jurnal Universitas Gunadarma Vol. 22, No. 3, 2017.

Ernawati, Diah (2019). Pengaruh Kualitas Produk, Inovasi Produk Dan Promosi Terhadap Keputusan Pembelian Produk Hi Jack Sandals Bandung. Jurnal Wawasan Manajemen Vol.7, No.1.

Gunawan, Tri (2017). Pengaruh Kualitas Produk, Harga, Promosi Dan Citra Merek Terhadap Keputusan Pembelian Honda Beat di Surabaya. Jurnal Sekolah Tinggi Ilmu Ekonomi Indonesia Surabaya Vol. 6, No. 4, 2017.

Hendro, Chardika Respatya, Wahyu, Hidayat (2018). Pengaruh Harga, Citra Merek, Kualitas Produk, Dan Promosi Terhadap Keputusan Pembelian IPhone Di Kota Semarang. Jurnal Universitas Diponegoro Vol. 7, No.4, 2018.

Kafabih, Abdullah (2018). Pengaruh Citra Merek, Kualitas Produk Dan Promosi Terhadap Keputusan Pembelian Produk Sim Card 
Telkomsel, Indosat Ooredoo Dan Hutchison 3 Indonesia Di Wilayah Jakarta Timur. Institut Bisnis Nusantara Jakarta Vol. 1, No. 2, 2018.

Manik, Cornelia. D (2015). Pengaruh Kualitas Produk, Harga dan Promosi Terhadap Tingkat Penjualan. Jurnal Ekonomi Universitas Pamulang Vol. 3, No. 1, 2015.

Sudaryanto, dkk (2019). Influence Of Brand Image, Price And Promotion On Consumer's https://scholar.google.co.id/

Buying Decision Of Fast Moving Consumer's Goods With Culture As A Moderating Variable In Basmallah Retail Store In Indonesia. International Journal Of Scientific \& Technology Research Volume 8, Issue 03, March 2019.

Musay, Fransisca Paramitasari. 2013. Pengaruh Brand Image Terhadap Keputusan Pembelian. Jurnal Fakultas Ilmu Administrasi Universitas Brawijaya. 